\title{
Development of Digital Skills and Impact on Advanced Excel Learning through the use of Edmodo virtual platform
}

\section{Desarrollo de Habilidades Digitales e Impacto en el Aprendizaje de Excel Avanzado a través del uso de plataforma virtual Edmodo}

TAVARES-AVENDAÑO, Juan Felipe †*, MEDINA-VELOZ, Gricelda, DE LA CRUZ-DURÓN, Raúl and HERNÁNDEZ-CHESSANI, David

\author{
Universidad Tecnológica del Norte de Aguascalientes \\ ID $1^{\text {st }}$ Author: Juan Felipe, Tavares-Avendaño / ORC ID: 0000-0001-8336-1546, CVU CONACYT ID: 586322 \\ ID $1^{\text {st }}$ Coauthor: Gricelda, Medina-Veloz / ORC ID: 0000-0002-1955-3620, CVU CONACYT ID: 228438 \\ ID $2^{\text {nd }}$ Coauthor: Raúl, De la Cruz- Durón / ORC ID: 0000-0002-4127-2024, CVU CONACYT ID: 972451
}

DOI: $10.35429 / J T E R .2019 .16 .5 .35 .42$

Received September 02, 2019; Accepted December 30, 2019

\begin{abstract}
Resumen
El proceso de enseñanza - aprendizaje que puede implementarse en una institución de Educación Superior para que un estudiante asimile los conocimientos y habilidades necesarios para el uso y dominio de un software tan comúnmente utilizado como es la hoja de cálculo Excel, debe considerar el uso de técnicas, estrategias y metodologías particulares si se trata de desarrollar competencias para el manejo de este software a nivel medio y avanzado. Esta investigación presenta los resultados obtenidos al haber utilizado como herramienta estratégica la plataforma virtual Edmodo dentro del curso de Informática II para el Programa Educativo de Contaduría, a fin de que el estudiante adquiera por un lado los conocimientos necesarios para el manejo del software mencionado, el desarrollo de habilidades digitales, la motivación hacia el aprendizaje, el fomento hacia la responsabilidad y proactividad para el estudio, así como la adquisición de hábitos distintos a los que puede desarrollar sin una tecnología de información como ésta.
\end{abstract}

Excel, Edmodo, Habilidad Digital

\begin{abstract}
The teaching - learning process that can be implemented in a Higher Education institution for a student to assimilate the knowledge and skills necessary for the use and mastery of a software as commonly used as the Excel spreadsheet, should consider the use of techniques, strategies and particular methodologies if it is to develop skills for the management of this software at medium and advanced level. This research presents the results obtained having used as a strategic tool the virtual platform Edmodo within the course of Computer Science II for the Accounting Education Program, so that the student acquires on one hand the necessary knowledge for the management of the mentioned software, the development of digital skills, the motivation to learn, the promotion of responsibility and proactivity for the study, as well as the acquisition of different habits to those that can develop without an information technology like this.
\end{abstract}

Excel, Edmodo, Digital Skill

Citation: TAVARES-AVENDAÑO, Juan Felipe, MEDINA-VELOZ, Gricelda, DE LA CRUZ-DURÓN, Raúl and HERNÁNDEZ-CHESSANI, David. Development of Digital Skills and Impact on Advanced Excel Learning through the use of Edmodo virtual platform. Journal of Teaching and Educational Research. 2019. 5-16: 35-42

$\uparrow$ Researcher contributing as first Author 


\section{Introduction}

Edmodo is an application that allows communication between teachers and students in the courses as a social networking service based on microblogging as a virtual private space in which messages, tasks, documents, activities and links can be facilitated, facilitating the use of a Classroom calendar, with homework, exams and activities and manage them.

In the Technological University of the North of Aguascalientes (UTNA) and in the rest of the State Technological Universities, the premise is to reduce the technological lag, moreover, to be at the forefront without losing sight of the fact that the most important thing is that the student obtains the knowledge, and in this case a tool that is available for the entire educational community is evaluated for free, it is also a current project, necessary and in the words of many people "very alive", which is constantly evolving and that every day has more surprises and improvements in its presentation and functionality.

\section{Justification}

This research paper responds to the need to know to what extent the Edmodo educational platform favors the learning of an application as used in the educational Accounting program as Excel, focusing mainly on the advanced use of it, an aspect that is not Easy assimilation by students. It is also sought, and in parallel to the methodology used by the teacher, to know those digital skills that can be developed with the use of this platform, the motivation generated by students in their use, as well as the responsibility and proactivity for their studies university students.

\section{Problem}

Students in the 2nd semester of the Accounting program have the opportunity to learn how to use the advanced functions of the Excel spreadsheet within the Computing II course. Being more complex issues to assimilate, there is a need to use teaching techniques, strategies and methodologies that facilitate the student's understanding. By using the Edmodo educational platform as an educational tool for this purpose, it is desired to know the impact it has on the learning and advanced management of the spreadsheet by students.

\section{Hypothesis}

The use of the Edmodo educational platform as a didactic tool, positively impacts on the learning of advanced Excel in the students of 2nd semester of the UTNA Accounting education program, in addition to that it fosters in them the development of digital skills, the motivation to learn and his responsibility and proactivity for the study.

\section{Goals}

\section{General Objective}

Knowing the impact that the Edmodo educational platform has on learning the Excel spreadsheet for 2 nd grade students. Semester of the UTNA Accounting Education program, as well as the development of their digital skills, their motivation to learn, their responsibility and proactivity for the study.

\section{Specific objectives}

Know the impact that the Edmodo educational platform has, its uses and benefits in education, the digital skills that are promoted with its use, the motivation towards the learning that it generates in the student, as well as the responsibility and proactivity for the study that It causes its use.

Identify the educational techniques, strategies and methodologies used to learn the Excel spreadsheet.

- Implement the Edmodo educational platform as a teaching tool for learning the advanced Excel spreadsheet in the Computer Science II course for the Accounting program.

\section{Theoretical framework}

The incorporation of Web 2.0 applications in training processes involves adding new communication styles, roles, forms of intervention, scenarios and a wide range of activities, which, in turn, require meeting a series of educational challenges; therefore, it is necessary for universities to assume the challenges that these tools represent within integrative approaches, that seek to create better educational spaces for exchange and training activity, and take advantage of the network potential (SCOPEO, 2009). 
Web 2.0 tools can be used with a competitive advantage to work collaboratively, since they are free and accessible platforms, which favor the motivation and interest of students when looking for strategies that benefit their learning (Islands \& Carranza , 2011).

The new technologies collaborate decisively in the adoption of the new educational model. According to Pérez, Rojas and Paulí, (2008, cited by Chamizo, 2013), there is greater wealth in the learning process with the use of new tools (platforms, forums, Edmodo, Facebook) providing common challenges, greater motivation for learning and the promotion of collaborative work.

Thus, it can be affirmed that teaching and learning from virtuality is a highly qualified means for the education of the immediate future, not only as a formative space, but as a social process of personalized and collaborative learning, with a teaching action that aims to satisfy the needs and interests of the group of students in the search for the development of their abilities through their interaction with the virtual context.

All this, through mutual support and collaboration, coupled with a climate of freedom, tolerance and care in which students live and experience that the educator is also educated, which leads to generate the autonomy and personal independence of the learner, so that it can transform its environment in an active way and according to the advances that society presents. This, then, would be the reflection of a proactive, cooperative and dynamic virtual teaching and learning that seeks the educational transformation that the current social context needs. Remember that you teach to learn and learn to teach (Perdomo \& Perdomo, 2012).

The use of tools can be enhanced as long as the teacher applies a methodology suitable for their respective use, which is why we talk about microblogs and specifically, the Edmodo tool since they are spaces willing to be used virtually. To make good use of these instruments, applications related to microblogging, and the "Edmodo" network that is designed for educational purposes should be known, these learning environments focus on facilitating student communication between groups and foster collective responsibility (Corrales \& González, 2015).
Edmodo is a free social learning platform that offers students access to the content of courses presented by teachers. With Edmodo, students and teachers can communicate with each other and connect by sharing useful ideas, problems and advice (Cauley, 2012).

Regarding educational activities, it offers a more interactive learning environment that makes students more interested in the class, more motivated to complete the assigned tasks and have better test results (Looi and Yusop, 2011; Enriquez, 2014).

Edmodo favors written production, information processing, collaborative work and self-management, the development of autonomy in the use of diverse tools and the revitalization of the teacher-student relationship. It has three functions in the learning process, the replacement function, the intermediary function and the complement function. In the replacement function, you can replace class hours that cannot be done in a classroom for different reasons.

In the role of intermediary, it can be used as a means to establish more open communication with the other members of the group and with the teacher in charge, as it facilitates the expression of students and fluency when exchanging opinions improving their degree of communication. And finally in the role of Edmodo as a complement, the teacher uses the tasks and functions of the tests in Edmodo to assign tasks and exams to the students, so they can be more independent in learning. [Motteram 2013].

The application is quite intuitive and organizes the groups, data, assignments and notes in a structured way, becoming the perfect learning management system (Learning Management System, LMS). The possibility of sending and receiving messages at all times enables collaborative and social advantages. The teacher has absolute control of the messages. The teacher has a tool that considerably improves the attention to their different groups, with instant exchange of information and personalized attention in each assignment. The student receives feedback regarding their homework with their grades and rewards (medals or badges) that are a motivating element (Sáez, 2013). 


\section{Research Methodology}

The preparation of this project was carried out in approximately 4 months by the professors of the Academic Body of Information Technology of the UTNA belonging to the Academy of Informatics, in collaboration with a couple of other professors, from Bodies Academics external to the university, one belonging to the UT of Aguascalientes and the other to the Academic Corps of the UT of Calvillo.

This research was conducted during the course of the Computer Science II course for students of the UTNA Accounting Education program. The first unit of the course proposes the theme of "Hello Advanced Electronics" where contents of a more complex level are treated with respect to those seen by students in the course of Computer Science I. For this reason, a learning environment was built in the Edmodo educational platform in which it would allow the student to take advantage of the benefits and potential of the tool for the benefit of their learning. Among these benefits, which were already mentioned in the "Theoretical Framework" section of this document, the following stand out:

- $\quad$ Opportunity to view, save and follow up on each and every one of the advanced topics of the Spreadsheet during the whole time of the course, in order to be able to consult them as many times as desired.

Consult and give a timely response to the Assignments (Tasks) carried out throughout the course, having the opportunity to be able to review your instructions permanently in order to send the activities carried out in each of the Advanced Excel practices in a timely manner.

Receive the qualifications and feedback of the teacher in a timely manner, with the benefit of being able to communicate directly with him through the platform to clarify any doubts about it.

In order to know the impact that the use of the Edmodo educational platform had on the learning of the Excel spreadsheet of the 2nd grade students.
During the four months of the UTNA Accounting Education program, a quantitative approach was used for this research, applying a questionnaire that allowed a quick view of the students' perception regarding the handling of this tool used to facilitate their understanding and assimilation of The themes of this course unit. With the application of this instrument, in addition, there was the opportunity to assess the development of some digital skills acquired when using the computer, the motivation generated in the student for learning the electronic sheet, in addition to analyzing other intrinsic values within This process, such as the promotion of the student's responsibility to monitor the content of the subject on their own, generating a more proactive attitude towards the study of this subject.

With a sample made up of $34 \%$ of men and $66 \%$ of women, the questionnaire was solved by a non-probabilistic and intentional sample of 64 students of the Accounting Education program distributed as follows: 21 of the CON2A Group, 22 of the Group CON2B and 21 of the CON2C Group. This questionnaire is presented below:

Please answer the following questions based on your experience in learning the Microsoft Excel tool (Medium / Advanced Level), in the Computer Science II course during the four-month period January-April 2019, which was supported with the use of the platform virtual learning Edmodo.

1. The structure and organization with which the notes and practices on Excel were published in Edmodo helped to better understand each of the topics.

2. The platform allowed me to communicate constantly with the teacher and my classmates to express my doubts related to the handling of Excel, the realization of the practices, as well as the evaluation and feedback of each of the topics.

3. Edmodo allowed me to deliver my Excel practices easily, with the opportunity to keep track of my portfolio of activities.

4. Having learned Excel through the Edmodo tool was attractive, interesting, useful and motivating.

5. Learning with the help of the Edmodo platform allowed me to improve my academic results in the Computer course. 
6. The Edmodo platform is compatible with my study habits, which allowed me to better organize my course learning activities.

7. The use of Edmodo helped to develop my experience and management of Excel.

8. The Edmodo platform allowed me to be proactive and responsible for my teaching-learning process

The scale used focused on the values: Nothing, Little, Pretty and Much, and the final version of the questionnaire can be found at the link: https://forms.gle/eE8cuA84568n8zhS9

\section{Results}

Once the previous questionnaire has been applied, the results obtained by each of the approaches are presented below:

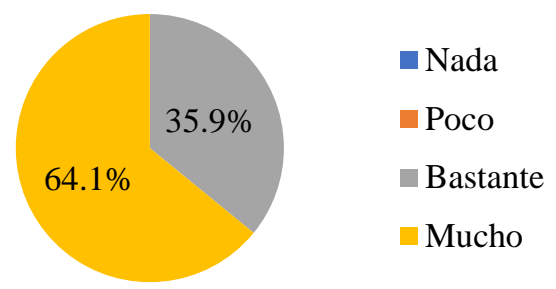

Figure 1 The structure and organization with which the notes and practices on Excel were published in Edmodo helped to better understand each of the topics

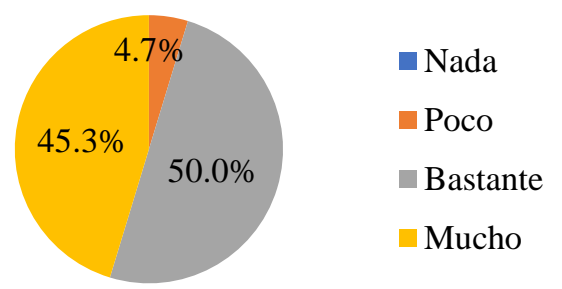

Figure 2 The platform allowed me to communicate constantly with the teacher and my classmates to express my doubts related to the handling of Excel, the realization of the practices, as well as the evaluation and feedback of each of the topics

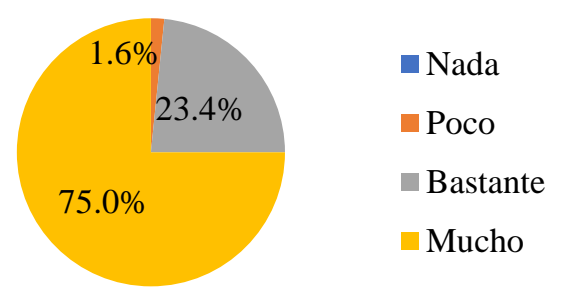

Figure 3 Edmodo allowed me to deliver my Excel practices easily, with the opportunity to keep track of my portfolio of activities

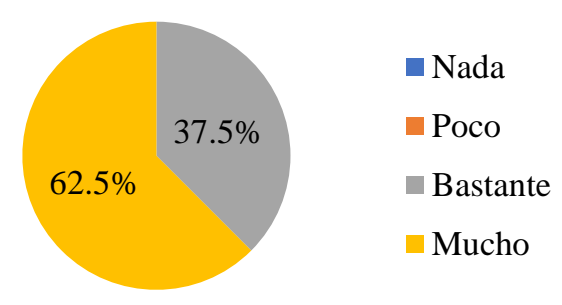

Figure 4. Having learned Excel through the Edmodo tool I found it attractive, interesting, useful and motivating

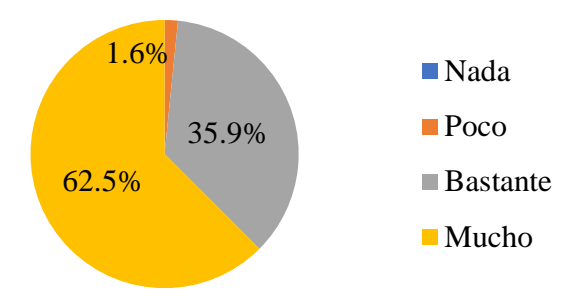

Figure 5 Learning with the help of the Edmodo platform allowed me to improve my academic results in the Computer course

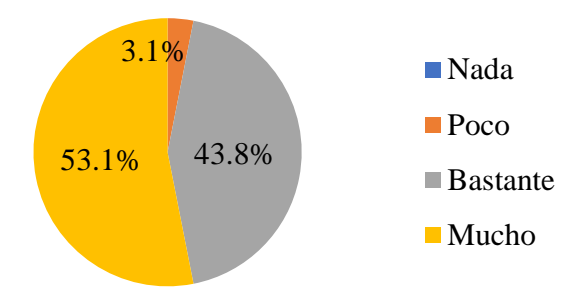

Figure 6 The Edmodo platform is compatible with my study habits, which allowed me to better organize my course learning activities

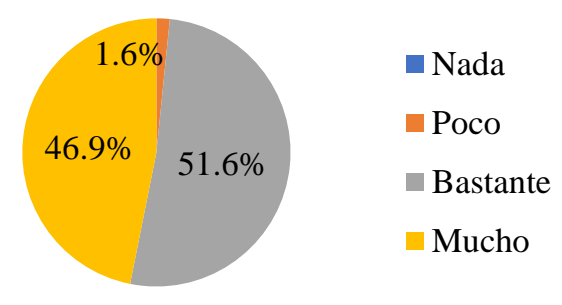

Figure 7 The use of Edmodo helped to develop my experience and management of Excel

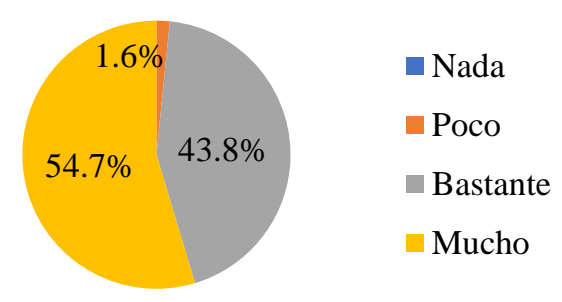

Figure 8 The Edmodo platform allowed me to be proactive and responsible for my teaching-learning process 
Analyzing each one of the previous graphs, it is observed that the majority of the answers expressed by the students are oriented to a preference (highlighting the "Pretty" and "Much" scales), in the study of the advanced spreadsheet with the support of the Edmodo educational tool.

Taking advantage of Edmodo's functionality to allow the student to easily deliver their Excel practices and thus be able to keep a record of their portfolio of activities, the highest result obtained in the survey appears with the "Much" scale with 75\% (23.4\% on "Pretty" scale). On the other hand, the functionality of the tool to allow the student to have constant communication with the teacher and his classmates to express doubts related to the handling of Excel and the realization of the practices, as well as with respect to the evaluation and feedback of the subjects, it was the aspect that obtained the lowest preference on the same scale, with a result of only $45.3 \%(50 \%$ on the "Pretty" scale).

Three aspects that obtain a high result equally on the "Much" scale are those related, on the one hand, to the Edmodo feature of allowing the publication of Excel notes and practices with a structure and organization such that they allowed the student better understand each of the issues, obtaining a result of $64.1 \%(35.9 \%$ in "Pretty" scale). On the other hand, and in a very significant way for the purposes of this investigation, it highlights the value on the same scale of $62.5 \%$ (37.5\% in "Pretty" scale), where the student expresses that the learning of Excel was attractive, interesting, useful and motivating through the educational tool. Thirdly, and in the same way with a result of $62.5 \%(35.9 \%$ in "Pretty" scale), on this scale, the student states that the use of Edmodo allowed him to improve his academic results in the Computer course.

A couple of results that stand out because more than half of the students give it a preference on a "Much" scale with $53.1 \%$ (43.8\% on a "Pretty" scale), and $54.7 \%$ (43.8\% on a scale "Enough"), respectively, are those related to Edmodo's compatibility with students' study habits, which allows them to better organize their course learning activities, as well as the proactivity and responsibility that allowed them to have this educational tool in its teachinglearning process.
Finally, and within the few aspects that the students gave a low percentage in "A lot" scale in relation to the aforementioned, it was related to the aspect where they state that Edmodo contributed to develop their experience and management of the sheet Excel advanced calculation, with $46.9 \%$ (51.6\% in "Pretty" scale).

\section{Conclusions}

The implementation of an educational tool in the teaching-learning process that supports and strengthens student learning requires clearly determining those aspects that always seek to improve. With this research, it was possible to study how the use of the Edmodo educational platform positively impacts the learning of the advanced Excel spreadsheet, as well as the way in which the development of their digital skills is encouraged, their motivation to learn, and strengthening their responsibility and proactivity for study. As could be seen in the results obtained, the hypothesis raised at the beginning of this investigation could be proven almost entirely.

At the end of the investigation, there was a quick vision of the students' perception regarding the management of the Edmodo platform for the understanding and assimilation of each of the advanced Excel topics, which allowed as a whole to see so clear results that mark a very clear trend towards preference in its use.

According to the aforementioned perception given by the same 2 nd grade students. four-month period of the UTNA Accounting Education Program in the use of the Edmodo educational platform for learning the Excel advanced spreadsheet, we can conclude the following:

Edmodo contributes to the student's experience and management of the advanced Excel spreadsheet.

- $\quad$ Edmodo is compatible with the student's study habits, allowing him to better organize his course activities, as well as to develop in him a greater responsibility and proactivity towards the study. 
- $\quad$ Edmodo helps the student to have better academic results in the Computer Science course, making Excel learning attractive, interesting, useful and motivating, through an organization and structure of the online platform that allows the student to better assimilate the subjects of the subject.

Edmodo allows the student, to a large extent, to easily deliver their Excel practices, thereby keeping a better record of their portfolio of activities.

Edmodo allows the student, to a lesser extent but in an important way, to have constant communication with the teacher and his classmates to express doubts related to the management of the advanced spreadsheet, to the realization of the practices, as well as to the evaluation and topic feedback.

For all the aforementioned and documented, it can be concluded that the Edmodo educational tool is an excellent option to use within the methodology, strategy and technique used by the teacher for the teaching of such a complex subject for students as it is the study of the advanced Excel spreadsheet, and can be applied in the same way in other subjects of this and other curricula of the UTNA and other institutions of higher education in the country.

\section{References}

Blasco, A., Lacruz, J., \& Sarsa, J. (31 de Enero de 2018). Percepción de los estudiantes al 'invertir la clase' mediante el uso de redes sociales y sistemas de respuesta inmediata. Revista de Educación a Distancia(57(6)). Recuperado el 20 de Mayo de 2019.

Cauley, P. (n.d.). A guide to explain it all. Retrieved May 2, 2018, recuperado de: https://melissaenderle.wikispaces.com/file/view /A+guide+to+explain+Edmodo.pdf

Corrales, C., \& González, L. (2015). Usos reales de la red social Edmodo en una experiencia de enseñanza y aprendizaje en el grado cuarto b de la institución educativa suroriental de Pereira. Recuperado el 21 de Mayo de 2019, de http://repositorio.utp.edu.co/dspace/bitstream/h andle/11059/5852/3713344678C823.pdf?seque nce $=1 \&$ is Allowed $=\mathrm{y}$
Chapilliquen Rodríguez, M.G. Competencias Digitales en estudiantes con diferentes estilos de aprendizaje, del séptimo ciclo de educación secundaria, desarrolladas a través de la red social educativa Edmodo en una institución educativa pública de la Unidad de Gestión Educativa Local No. 03, el año 2015.

Enriquez, M. (2014). Students' Perception on the Effectiveness of the Use of Edmodo as a Supplementary Tool for Learning. Paper Presented at the DLSU Research Congress 2014: Philippines. De La Salle University, Manila, Philippines. March 6-8, 2014. Recuperado de: http://www.dlsu.edu.ph/conferences/dlsu_resear ch.../_pdf/LLIII-010.pdf.

Hernández Raygoza, J. (2015). Uso de la Plataforma Edmodo y Blended Learning en el Aprendizaje de Adultos Mayores.

Hernández, J. (1 de Octubre de 2015). Tecnológico de Monterrey. Recuperado el 5 de Mayo de 2019, de https://repositorio.itesm.mx/handle/11285/6223 52

G. Motteram, Innovations in learning technologies for English language teaching, pp. 106 166, 2013.

Gómez Yepes, E. (2017). Uso de un ambiente virtual como apoyo al proceso de enseñanza y de aprendizaje de las matemáticas en el grado $9^{\circ}$ de la Institución Educativa Industrial María Auxiliadoa de Condoto.

Islas, C., \& Carranza, M. d. (2011). Uso de las redes sociales como estrategias de aprendizaje. ¿Transformación educativa? Revista de innovación educativa, 3(2). Recuperado el 1 de Mayo de 2019, de http://www.udgvirtual.udg.mx/apertura/index.p hp/apertura/article/view/198/213

Looi, C.Y., \& Yusop, F.D. (2011). Potential use of social networking tool to assist reading comprehension: Implications for practice and future research. Jurnal Pendidikan 31(1),189201. Recuperado de: https://umexpert.um.edu.my/file/publication/00 006651_78950.pdf. 
Meza Coronado, C.P., \& Escobedo del Carpio, E.G. (2015). Uso del entorno personal de aprendizaje (PLE) para el desarrollo de actitudes hacia la ciencia en estudiantes del quinto grado de educación secundaria de una institución educativa pública de Arequipa.

Perdomo, Y., \& Perdomo, G. (2012). Elementos que intervienen en la enseñanza y aprendizaje en línea. Apertura, 4(1). Recuperado de: http://www.udgvirtual.udg.mx/apertura/index.p hp/apertura/article/view/215/230.

Sáez, J. M. (2013). Uso de Edmodo en Proyectos Colaborativos Internacionales en Educación Primaria EDUTEC. Revista Electrónica de Tecnología Educativa(43). Recuperado el 15 de Mayo de 2019, de http://www.edutec.es/revista/index.php/edutece/article/view/329.

SCOPEO. (2009). Formación Web 2.0. Salamanca, España: Monográfico SCOPEO, $\mathrm{n}^{\circ}$ 1. Recuperado el 26 de Mayo de 2019, Recuperado de: http://scopeo.usal.es/images/documentoscopeo/ scopeom001.pdf

Walsh, K. (5 de Junio de 2011). 7 motivos para usar Redes Sociales en Educación. Recuperado el 28 de Mayo de 2019, de: http://www.escuela20.com/facebook-edmodoredes-sociales/articulos-y-actualidad/7-motivospara-usar-redes-sociales-eneducacion_3037_42_4535_0_1_in.html

\section{Acknowledgments}

A well-deserved recognition is extended to the students of the educational program of Accounting of the UTNA who participated throughout this investigation during the course of Computer Science II, from its beginning and until obtaining the results. Likewise, the support and dedication of the professors, both from the UTNA, and the UT of Aguascalientes and the UT of Calvillo for the realization of this project, is appreciated. 